\title{
The effect of teaching experience and training on teachers' performance of state senior high schools
}

\author{
Zulkarnain Zulkarnain ${ }^{1}$, Happy Fitria ${ }^{2}$, Yenny Puspita ${ }^{2}$ \\ ${ }^{1}$ Sekolah Menengah Atas Negeri 1 Buay Sandang Aji, Indonesia \\ ${ }^{2}$ Universitas PGRI Palembang, Indonesia
}

\begin{tabular}{l} 
Article Info \\
\hline Article history: \\
Received Jul $12^{\text {th }}, 2021$ \\
Revised Aug $8^{\text {th }}, 2021$ \\
Accepted Aug $30^{\text {th }}, 2021$ \\
\hline
\end{tabular}

\section{Keyword:}

Teachers' performance

Teaching experience

Training

\begin{abstract}
This study aimed to determine: (1) the effect of teaching experience on teachers' performance; 2) the an effect of training on teachers' performance; and (3) the effect of training on teachers' performance. The data in this study were collected through distributing questionnaires to respondents. The results of filling out the questionnaire were analyzed by using multiple regression analysis through the $\mathrm{t}$ test, $\mathrm{F}$ test, and determination coefficient test. The population in this study was 703 State Senior High School teachers in Ogan Komering Ulu Selatan Regency. The sample in the study was taken by using purposive sampling technique; thus, the sample of this study were 160 teachers. The results of the study found that: (1) there was an effect of teaching experience on the performance of teachers; 2) There was an effect of training on the performance of the teachers; 3) There was an effect of teaching experience and training simultaneously on the performance of teachers.
\end{abstract}

(C) 2021 The Authors. Published by IICET.

This is an open access article under the CC BY-NC-SA license

(https://creativecommons.org/licenses/by-nc-sa/4.0

\section{Corresponding Author:}

Zulkarnain, Z.,

Sekolah Menengah Atas Negeri 1 Buay Sandang Aji, Indonesia

Email: zulkarnainedihendry@gmail.com

\section{Introduction}

The teacher is a professional position, as described in article 1 of the Law of the Republic of Indonesia Number 14 of 2005 concerning Teachers and Lecturers which stated that "Teachers are professional educators ...". Teacher is a profession / position that requires special skills as a teacher. Therefore, a teacher in carrying out his role and duties must be accompanied by certain skills education, in the form of skills, honesty, and so on. Through their roles and functions, teachers as professionals function as learning agents in order to achieve educational goals. The role and function of the teacher will be reflected in how the teacher works. Teacher performance can be seen when the teacher implements learning at school.

The work done must be in accordance with the established performance standards. The effect of teaching experience on teacher performance, in theory, can be explained that the more teaching experience the teacher has, the better his performance will be. This is because experience will bring learning for the teacher himself to be more familiar with his work environment and to understand the solutions that need to be done to overcome the problems that occur [1], "work experience is assessed based on teaching experience in the form of work years that have been carried out by the teachers; a collection of lesson plan files made; and awards won. According to his tenure, [2] Classified teaching experience as "grouped teachers in three levels of teaching experience (3-6; 7-10 and more than 10 years)". Schuler categorized the teaching experience of teachers into three categories, namely teaching experience for 3-6 years; 7-10 years; and more than 10 years. 
Researchers made preliminary observations to determine the population to be studied about the effect of teaching experience on teacher performance. In initial observations, researchers did this at SMA Negeri 1 Buay Sandang Aji. From initial observations, it can be seen that the potential and expertise of teachers possessed are of course still not sufficient to carry out the learning process, even though the skills of teachers are very supportive in the educational process. Teacher performance, of course, is greatly influenced by how long the teacher has taught, therefore the teacher's experience in teaching can be used to measure the teacher's performance.

Apart from experience which is an individual variable, learning or training is a factor that affects teacher performance. [3] explains in her journal entitled The Effect of Education and Training on the Performance of Civil Servants at the Regional Secretariat of Malang City that improving the quality of educators is directed to be able to support the state administration system which contains the main functions, namely the function of government administration, the function of development and the function of service. Public

The training aims to improve teacher skills so that they are better at working and carrying out their duties as a teacher. For example, in the 2013 curriculum implementation training, many teachers have attended the training, but the results obtained by the teachers are still confused in the implementation of the 2013 curriculum. So, the conclusion is that the training followed by the teacher has not been optimally embedded in the teacher and his performance. Researchers also asked several teachers about the differences in the performance of teachers who already had long enough teaching experience and new ones. The results of these observations resulted in the answer that many public high school teachers in Ogan Komering Ulu Selatan district, even though they had quite a lot of teaching experience, their performance did not have a significant difference with teachers who had relatively little experience. From these observations, the initial conclusion of the researcher was that the teacher's teaching experience had no effect on improving their performance.

The teacher is one of the factors that influence education. That is, teacher performance affects learning processes and outcomes. Teacher performance is indirectly shaped by teaching experience. The more teaching experience, the better the implementation of learning. In addition, the more training the teacher participates in, the better the skills the teacher will acquire in improving their performance.

Based on the descriptions above, the researcher was interested in conducting a research to find out the Effect of Teaching Experience and Training that they have attended on Teachers' Performance of State High Schools in Ogan Komering Ulu Selatan Regency.

\section{Method}

Research on the effect of teaching experience and training on teachers' performance of state high school in Ogan Komering Ulu Selatan District was a quantitative study, with an experimental method that used observations and questionnaires. This study consisted of three variables in the form of two independent variables and one dependent variable. The independent variables in this study were teaching experience and training. While the dependent variable in this study was teacher performance.

The population in this study were State Senior High School (SMA) teachers in Ogan Komering Ulu Selatan Regency on 21 public schools. The sample in the study was taken by using purposive sampling technique, namely sampling with criteria [1]. The criteria that the researcher proposed were teachers in public high schools. So the sample of this study were 160 people from five public high schools from a population of 703 people on 21 public high schools.

The technique collecting data used in this study were through distributing questionnaires to respondents. The results of filling out the questionnaire were analyzed by using multiple regression analysis through the $t$ test, $\mathrm{F}$ test, and determination coefficient test.

\section{Results and Discussions}

\section{Normality Test}

The normality test aimed to test whether the dependent variable and independent variable regression model both had a normal distribution or not, so to test whether the research data were normally distributed or not can be detected through One-Sample Kolmogorov-Smirnov Test and graph analysis.

The normality test result found that the Asymp. Sig. (2-tailed) for the teacher performance variable $(\mathrm{Y})$ of 1.128 , the teaching experience variable (X1) of 1.118, and the training variable (X2) of 1.127. As it is known that if the value of Asymp. Sig. (2-tailed) $>0.05$, the data are normally distributed, and vice versa if the Asymp value. Sig. (2-tailed) $<0.05$, the data are not normally distributed. Thus, the data on teachers' performance variables, teaching experience, and training were normally distributed. 


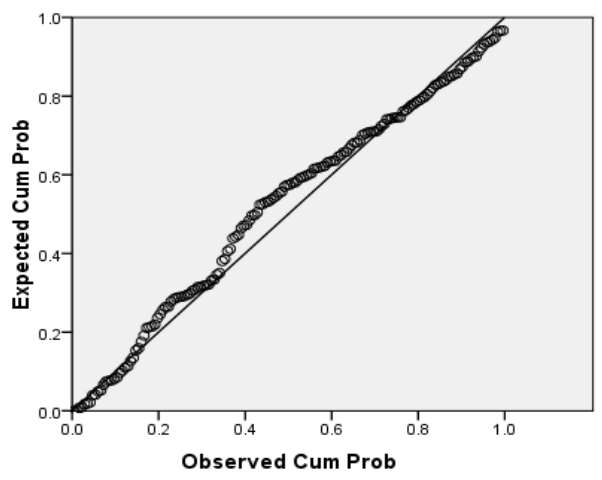

Figure 1. Normality Plot Analysis

Based on the analysis by using a normal probability plot graph, it can be seen that the data for each variable used in the study were normally distributed. This was evidenced by spreading the data around the diagonal line and following the diagonal line. Thus, the regression model had met the normality assumption.

\section{Homogeneity Test}

The homogeneity test of the data is needed to prove the equation for the variation of the groups that make up the sample. The test criteria is a significance value $<0.05$, so the group variants are not the same. Conversely, if the significance value $>0.05$, the variance of the data group is the same. From the output, it can be seen that the significance value was $0.247>0.05$. So, it can be concluded that the variant data from the distribution of questionnaires for the variables of teaching experience, training and teacher performance were homogeneous.

\section{Linearity Test}

Linearity test is used to determine whether the regression obtained is "meaningful" when used to make conclusions between the dependent variable being analyzed. The linearity test of the independent variables and the dependent variable was carried out by using One-way Anova in the SPSS program. Version 22.0 with a significance level of $5 \%(\alpha=0.05)$.

Linearity test showed the significant value for teacher performance * teaching experience variables was 0.000 , and teachers performance * training variable was 0.001 . That is, the significant value of the teacher performance variable * teaching experience and the teacher performance * training variable were smaller than 0.05 , it can be concluded that the teaching and training experience variables had a linear relationship with the teachers' performance variable.

\section{Hypothesis Testing Results}

\section{Partial Hypothesis Testing}

Hypothesis testing partially or testing the effect of each independent variable on the dependent variable or the effect of the teaching experience variable (X1) on the teachers' performance variable (Y), and the training variable $(\mathrm{X} 2)$ on the teachers' performance variable $(\mathrm{Y})$ by looking at the probability value (significance ) which was obtained. The test results can be seen in Table 2

Table 2. Hypothesis Test Results Partially

\begin{tabular}{cllc}
\hline Model & & $\mathrm{t}$ & Sig. \\
\hline & (Constant) & 3.873 & .000 \\
& teaching experience (X1) & 3.484 & .001 \\
& training (X2) & 2.548 & .012 \\
\hline
\end{tabular}

Based on Table 2, it is known that the probability value (significance) for the Teaching Experience variable was 0.001 . That is, the probability value (significance) $0.001<0.05$, thus $\mathrm{Ho}$ was rejected and $\mathrm{Ha}$ was accepted. It can be explained that there was an effect of teaching experience on the performance of teachers at SMA Negeri Ogan Komering Ulu Selatan Regency. 
From Table 2, it is also known that the probability value (significance) for the training variable was 0.012 . That is, the probability value (significance) $0.012<0.05$, thus Ho was rejected and Ha was accepted. It can be explained that there was an effect of the training that had been followed on the performance of the teachers of SMA Negeri Ogan Komering Ulu Selatan Regency.

\section{Simultaneous Hypothesis Testing}

The $\mathrm{F}$ test is used to determine whether the independent variables simultaneously (jointly) affect the dependent variable.

\begin{tabular}{|c|c|c|c|}
\hline Model & & $\mathrm{F}$ & Sig. \\
\hline \multirow[t]{3}{*}{1} & Regression & 11.541 & $.000^{\mathrm{a}}$ \\
\hline & Residual & & \\
\hline & Total & & \\
\hline
\end{tabular}

The test results simultaneously obtained the probability value sig. F was $0.000<0.05$. Thus Ho was rejected and $\mathrm{Ha}$ was accepted. It can be explained that there was an effect of teaching experience and training that had been followed on the performance of SMA Negeri Ogan Komering Ulu Selatan Regency.

\section{Coefficient of Determination}

Coefficient of Determination test result showed the value of the correlation/ relationship (R), which was 0.658. In addition, it also explains the percentage of influence of the independent variables (teaching experience and training) on the dependent variable (teachers' performance) called the coefficient of determination which is the result of squaring R. From this output, the coefficient of determination (Adjust R Square) was 0.407 , which implies that the influence of the independent variables (teaching experience and training) on the dependent variable (teachers' performance) was $40.7 \%$, while the remaining $59.3 \%$ was influenced by other variables not examined in this study, such as motivation variables. work, work discipline, principal academic supervision, and other variables that could affect teachers' performance.

\section{Discussions}

\section{The Effect of Teaching Experience on Teacher Performance}

The results of hypothesis testing showed that the teaching experience variable had a significant effect on teachers' performance. The results of the study showed that the teaching experience had a contribution on teachers' performance by $29.6 \%$. This meant that the teaching experience that a teacher went through would help determine certain steps that could support the success of their work in achieving predetermined work standards. As in the learning process, teachers were required to be able to develop teaching materials through various media and varied methods so as to make students more interested in investigating more about the material being taught so that in the end they are able to achieve the learning objectives.

The teaching experience of public high school teachers in Ogan Komering Ulu Selatan district was measured by the number of lengths of teaching indicated by the time period. Public high school teachers in Ogan Komering Ulu Selatan district had varied teaching experiences. Starting from 1 year to 40 years. The longer the working period, the more various experiences would be gained at work. Based on the research that researcher had conducted at the State Senior High School in Ogan Komering Ulu Selatan Regency, the data obtained from the research findings showed that there was a significant contribution between teaching experience and the performance of public high school teachers in Ogan Komering Ulu Selatan Regency.

Teaching experience for a teacher is deemed necessary, because this experience has a very important role in the development of their job or profession. Teachers are not a profession that is run simply because the teaching profession has established work standards like professional teachers, where teachers are required to be able to master in depth and develop teaching materials so that students can understand and achieve the specified learning objectives.

This is according to what Uno (2007: 17) argued, basically changes in behavior that can be shown by students are influenced by the educational background and experiences of a teacher. So through teaching experience helps teachers in achieving teacher professional standards that must be met in accordance with the research results described above.

\section{The Effect of Training on Teachers' Performance}

The results of hypothesis testing show that the training variable had a significant effect on teachers' performance. The results of the research showed that training had a contribution on teachers' performance by $31.4 \%$. 
Training had an effect on teachers' competence, both pedagogical competence, personality, social and professional competences. The teachers of SMA Negeri Ogan Komering Ulu Selatan Regency had high motivation in participating in the training. This can be seen from the number of teachers who attended training during the teaching period. Of the 160 teachers, 19 had never attended any training and 141 teachers had attended training. In general, the training that was attended reached the provincial level and was relevant based on the quality, quantity, time and cost aspects.

The results of this study are in accordance with the opinion expressed by Armstrong (2004: 191) that training is useful to help teachers develop skills and levels of teacher abilities. The performance of people in their work will improve due to training. Based on research that had been conducted at the State Senior High School in Ogan Komering Ulu Selatan Regency, the data obtained from the research findings show that there was a positive and significant contribution between training on teachers' performance in SMA Negeri Ogan Komering Ulu Selatan Regency. Training provideds a relative contribution of 36\% to teachers' performance.

In addition, there are several relevant research results that strengthen the results of this study. Training (education and training) had a positive effect on teachers' performance. This was because training was an effort in developing human resources for an organization, but improving teachers' performance in each organization had its own percentage, as well as public high school teachers in Ogan Komering Ulu Selatan district. Therefore it can be concluded that with the training for teachers experiencing positive changes for teachers in terms of knowledge, abilities and skills which had increased with the development of human resources such as this training.

\section{The Effect of Teaching Experience and Training Simultaneously on Teacher Performance}

Teaching experience and training simultaneously had a significant effect on teachers' performance. That was, simultaneously there was a significant influence between Teaching Experience (X1) and Training (X2) on the performance of SMA Negeri Ogan Komering Ulu Selatan District teachers.

Teaching and training experiences have an important role in improving teacher performance. Teachers have special characteristics, so they need special attention and services to improve their competencies. The teacher is a major role in education because it directly fosters, influences and develops students' abilities. Students can become quality human resources if they are guided by qualified teachers.

Based on research that had been conducted on public high school teachers in Ogan Komering Ulu Selatan district, the data obtained from the research findings showed that there was a significant contribution between teaching experience and training on the performance of public high school teachers in Ogan Komering Ulu Selatan district. The magnitude of the simultaneous contribution of training and teaching experience to teacher performance was as follows: training had a contribution of $40.7 \%$. The remaining $59.3 \%$ was influenced by other factors which were not the focus of discussion in this study.

Based on the results of the analysis, the teaching experience and training had an effect on teachers' performance. Teaching experience, training tended to make teachers had better competence. Based on the results of data analysis, teaching experience, training had a major contribution to the performance of teachers in SMA Negeri in Ogan Komering Ulu Selatan Regency.

\section{Conclusions}

Based on the results of research and discussion, the following conclusions can be drawn. There was an effect of teaching experience on the performance of teachers of SMA Negeri of Ogan Komering Ulu Selatan Regency. The teaching experience that a teacher went through would help determine certain steps that could support the success of their work in achieving predetermined work standards. There was an effect of training on the performance of the teachers of SMA Negeri of Ogan Komering Ulu Selatan Regency. Training had an effect on teachers' competence, both pedagogical competence, personality, social and professional competences. The teachers of SMA Negeri of Ogan Komering Ulu Selatan Regency had high motivation in participating in the training. There was an effect of teaching experience and training simultaneously on the performance of teachers in Ogan Komering Ulu Selatan District. The data obtained from the research findings showed that there was a significant contribution between teaching experience and training on the performance of public high school teachers in Ogan Komering Ulu Selatan district. 


\section{References}

Sugiyono.(2016).Metode Penenlitian Kombinasi (Mixed Mehtods). Bandung: Alfabeta.

Adeyemi. (2008). Teachers' Teaching Experience and Students' Learning Outcomes in Secondary Schools in Ondo State, Nigeria. Asian Journal of Onformation Teachnology 7 (5): 201-209 2008.

Dartha, I.K. (2010). Pengaruh Pendidikan dan Pelatihan (DIKLAT) terhadap Kinerja Pegawai Negeri Sipil pada Sekertariat Daerah Kota Malang. Jurnal Ekonomi MODERANISASI Volume 6, Nomor 2, Juni 2010. 